\title{
CONTROLLED CliniCAL TRIALS WiTH DOPING SUBSTANCES IN SPORTS LAW
}

\author{
Erwin Deutsch*
}

The research ethics committee of a German medical university recently faced a totally new problem. The department for sports medicine had asked the committee to approve a protocol for a controlled clinical trial about the efficacy and safety of doping substances in cycling. This article considers the difficulties of the German law on this matter.

\section{INTRODUCTION}

Doping can be defined as the non-physiological augmentation of the physical abilities of a person. Doping by sportspeople is not allowed, and the circulation or use of doping substances, and the aiding thereof, is also a crime. The German Parliament, with the help of experts, has compiled a list of doping substances. That list is in the annex to the German statute regulating the sale of medicinal products: the Arzneimittelgesetz (AMG). ${ }^{1}$

The research ethics committee of a German medical university was recently asked by its department for sports medicine to approve a protocol for a controlled clinical trial investigating the efficacy and safety of doping substances in cycling. A number of legal questions emerged for that committee from the treatment of doping substances in the AMG. The first of these questions was whether clinical trials to test the safety and efficacy of doping substances are generally permissible, or permissible only under the special circumstances of the trial. Then there was the problem of whether a sportsperson would be personally liable for doping, possibly even under the criminal law. There was also a problem as to how far the interests of third persons (for example, advertisers in connection with the sport) are protected. Finally there was the problem of whether the law of the state where the sport took place or some general rules of the sports' associations (mostly domiciled in Switzerland) are to be applied.

* Dr iur, MCL (Columbia, NY) Professor of Law, Göttingen University. Contributing authors: Jana Dumrese, Martha Szabó, Hendrik Matz and Thore Iversen. It is with much pleasure that I participate in this honouring of an esteemed colleague. Our mutual interest in medico-legal matters has brought us together many times over the years. My best wishes to Professor Atkin for further years of fulfilment in teaching and research.

1 This list was compiled pursuant to s 6a, subs 21, sentence 1 of the Arzneimittelgesetz (AMG). 
This article examines some of these problems. First, as background, it discusses whether doping substances fit the definition of "medicinal products" in the AMG, to establish how far the AMG might apply to doping substances, and in particular how the provisions about controlled clinical trials might apply to tests on doping substances. It then discusses the ban on doping substances contained in the AMG, and to what types of activity this ban applies. The possible conflict between the rules on controlled clinical trials and the ban on doping substances is then explored. The various methods of statutory interpretation which can be used to resolve this conflict are outlined and applied. Finally, the article discusses the problem of which law would be applicable should an issue arise concerning the use of doping substances in controlled clinical trials where there are crossborder considerations.

\section{DOPING SUBSTANCES AS MEDICINAL PRODUCTS \\ A Doping Substances and the Prohibition on Doping Substances}

Section 6a, subs 2a of the AMG relevantly states:

(2a) Es ist verboten, Arzneimittel ${ }^{2}$ oder Wirkstoffe, die im Anhang zu diesem Gesetz genannte Stoffe sind oder enthalten, in nicht geringer Menge zu Dopingzwecken im Sport zu erwerben oder zu besitzen, sofern das Doping bei Menschen erfolgen soll ..

In translation, the subsection states that it is illegal to possess, for the purpose of doping in sport, more than a small amount of a medicinal product which is or contains a substance listed in the annex to the statute. ${ }^{3}$

\section{B Doping Substances as Medicinal Products}

The first question to be answered is whether doping substances are medicinal products for the purposes of the AMG? ${ }^{4}$ Medicinal products are defined in subs 1 of s 2 of the AMG:

(1) Medicinal products are substances or preparations made from substances which:

1. are intended for use on or in the human ... body and are intended for use as remedies with properties for the curing, alleviating or preventing of human ... diseases or disease symptoms or

2 The word "Arzneimittel" can be translated in many ways, including "drugs" or "medicinal products". In this article, the translation "medicinal products" is used, as it is in the translation of the AMG provided by the Language Service of the German Federal Ministry of Health, made available at <www.gesetze-iminternet.de>. All English quotes from the AMG in this article are taken from that translation.

3 See Arno Kloesel and Walter Cyran Arzneimittelrecht - Kommentar (Deutscher Apotheker Verlag, Stuttgart, 2010) s 6a, no 8; and Erwin Deutsch and Andreas Spickhoff Medizinrecht (6th ed, Springer Verlag, Berlin, 2008) at 1219 and 1547.

4 Kloesel and Cyran, above n 3, at s 2, abs 2; Deutsch and Spickhoff, above n 3, at at 1219 and 1547; and Wolfgang Rehmann Arzneimittelgesetz (4th ed, Verlag CH Beck, Munich, 2014) at s 6a, no 2. 
2. can be used in or on the human ... body or can be administered to a human being ... either:

a) to restore, correct or to influence the physiological functions through a pharmacological, immunological or metabolic effect, or

b) to make a medical diagnosis.

Moreover, according to subs 2, medicinal products include objects which "contain a medicinal product ... and which are intended to come into either temporary or permanent contact with the human ... body". Subsection 3 lists what is not a medicinal product. ${ }^{5}$ That list includes foodstuffs, organs for transplantation, dressings and surgical sutures, among other things.

The typical doping substance is a chemical combination used to enhance the corporal facilities of a sportsperson and is, according to the generally accepted interpretation, a medicinal product within the meaning of s 2, subs 1 of the AMG. Other means of enhancing performance, such as electric motors on a bicycle, do not fall within the definition of medicinal products in the AMG.

\section{Marketing of Medicinal Products}

Under European law there is no free market for medicinal products in general. Under German law medicinal products have to be certified in accordance with s 21 of the AMG before they can enter the market. There are a few exceptions to this rule, such as clinical trials and compassionate use. ${ }^{6}$ However, no controlled clinical trials are required before a drug can be added to the list of unauthorised drugs for doping purposes. Some of the substances are certified for use in the medical field, others are not. The former have successfully undergone clinical trials, the latter have never been tried. Even if a medicinal product has undergone clinically controlled trials, these trials will not have been undertaken for doping purposes and therefore are not to be regarded in this respect as controlled clinical trials run in accordance with ss 40 and following of the AMG (the rules regulating controlled clinical trials). Nevertheless, some medicinal products approved for medical purposes can be used to enhance the abilities of sportspeople and are not to be regarded as approved drugs. The trial was for a certain purpose and only concerns the safety and efficacy of the drug for medicinal use, not for other uses. ${ }^{7}$

\section{RULES ABOUT CONTROLLED CLINICAL TRIALS}

\section{A Principles of Controlled Clinical Trials}

The rules regulating controlled clinical trials, contained in ss 40 and following of the AMG, are very elaborate. They distinguish between clinical trials on persons suffering from a disease to be

5 See Deutsch and Spickhoff, above n 3, at 1211.

6 Kloesel and Cyran, above n 3, at s 21, abs 2, no 5.

7 Rehmann, above n 4, at s 40, no 1. 
treated by the substance being trialled, and those on persons in general. They require informed consent. A new substance being trialled must not be dangerous to the patients or probands. In this respect the German, and more broadly the European, approach differs from the American. Europe relies first on a safe test, and secondly asks for informed consent. In the United States it is the opposite: informed consent comes first and the safety of the test comes second. ${ }^{8}$

\section{B Rules for Controlled Clinical Trials}

Controlled clinical trials usually compare two groups of persons. One group receives the new medication (the test group) and the other receives the standard medication (the control group).

A trial is clinical if the doctors involved do not know who is in the control group and who is in the test group. Normally the patients and probands are randomly distributed to the test group and the control group. These test and control groups can be enlarged to a number of cohort studies which allow a closer comparison. If the doctors involved in administering the trial do not know who is in which group, it is a blind study. If even the doctors leading the trial do not know who belongs to which group, it is a double blind study.

There are special rules for trials involving minors and trials involving persons incapable of giving informed consent themselves. In these cases, informed consent has to be given by someone in the position to act for the minor or the person incapable of giving consent. ${ }^{9}$

The sponsor of a controlled clinical trial must carry accident insurance for the trial participants. The insurance companies believe this insurance only covers material damage, but there is some scholarly opinion that protection for non-material damage is included in such policies. ${ }^{10}$

A controlled clinical trial requires the approval of an ethics committee. An ethics committee is a group of doctors and a few laymen, including at least one lawyer, who have to approve the trial protocol in advance. ${ }^{11}$ If the clinical trial involves several investigators (that is, several clinics will take part in the trial) there will be a leading ethics committee from one clinic, and the other ethics committees from the other clinics will work closely with that committee. Without approval by the local ethics committee the clinical trial cannot begin. In Germany the approval of a state agency is also necessary. ${ }^{12}$

8 Deutsch and Spickhoff, above n 3, at 918

9 Section 41, subss 2 and 3

10 Adolf Laufs, Christian Katzenberger and Volker Lipp Arztrecht (6th ed, Verlag C H Beck, Munich, 2009) at 486 .

11 Deutsch and Spickhoff, above n 3, at 1000.

12 In the author's opinion this is certainly too much. 


\section{CRIMINAL PROHIBITIONS ON DOPING SUBSTANCES}

\section{A The 2009 Law Change}

The AMG prohibits the introduction of doping substances into the market and the use of them by sportspeople. ${ }^{13}$ Therefore persons who circulate doping substances as well as persons, normally doctors, who administer them, are criminally liable. Until recently there was an issue as to whether the sportsperson was also criminally liable for aiding the criminal act. ${ }^{14}$ The previously prevailing opinion was that the norms against using the doping substance were not applicable because they were to be regarded as highly personal. Otherwise the sportsperson would have been criminally liable in nearly all cases where the substance was administered.

This opinion was rejected in the revision of s 6a of the AMG in 2009, which criminalised the possession of doping substances. ${ }^{15}$ A sportsperson is no longer protected from criminal liability because he or she is now liable for the possession of the prohibited substance, if it is more than a small amount. The term possession is used as in the law of property. ${ }^{16}$

\section{B Small Amount}

It is difficult to determine what a "small amount" is. The most recent decision which defined "small amount" is that of the Federal Supreme Court of 17 November 2011. ${ }^{17}$

The accused in that case was interested in chemistry and had a small laboratory at home where he worked with amphetamine derivatives. Because of a prostate carcinoma, he suffered from erectile dysfunction. While working in his laboratory he found a crystalline substance which he used to treat his dysfunction. He put the substance into small bags for future consumption. In total the bags contained 915 grams of methamphetamine hydrochloride.

The lower court had held that was not a "small amount" of the medicinal product. The Federal Supreme Court partially upheld the lower court, but also held "small amount" was up to 10 grams of the substance when the active ingredient ${ }^{18}$ was looked at. The Court relied heavily on the chemical results of tests of the substance. The Court followed former cases which established what a "small amount" was by looking to the actual effect and intensity of the substance.

13 AMG, ss 6a and 96; Kloesel and Cyran, above n 3, at s 96 no 2a; and Deutsch and Spickhoff, above n 3, at 1534.

14 Rehmann, above n 4, at s 6a no 1; and Kloesel and Cyran, above n 3, at s 6a, no 55a.

15 Deutsch and Spickhoff, above n 3, at 1534.

16 Kloesel and Cyran, above n 3, at s 6a, no 46.

17 BGH A\&R 2012, 343 StR 315/10, 17 November 2011.

18 Wirkungsbestimmende Base. 


\section{Influence of the New Prohibition}

Because the possession of doping substances was not criminalised until 2009, the interpretation of the other criminal statutes relating to doping substances will be affected. What was aiding and abetting a criminal act prior to 2009 has now become a criminal act in itself. All the problems of whether someone has produced, used or distributed doping substances have now become easier because of inclusion of the words "possession of more than a small amount".

\section{RECONCILING CONFLICTING NORMS}

\section{A The Conflicting Norms and Options for Resolving the Conflict}

The text of the AMG was totally revised and re-enacted by the German Parliament in 2012. Therefore s 6a of the AMG, which was originally added in 1998, cannot be regarded as a later norm that supersedes earlier norms. All the norms are equal.

If medical experimentation with doping substances in sports is allowed, then two norms of equal status will be in conflict with each other: $\mathrm{s}$ 6a of the AMG, which states the possession of more than a small amount of doping substances for sporting purposes is not allowed; and s 40 and following of the AMG, regulating controlled clinical trials on medicinal products. Potentially there are four ways this conflict can be resolved:

(1) One or both norms can be interpreted in such a way that there is no conflict.

(2) If one norm is superior to the other (that is, if it is more specific), that norm will take precedence.

(3) If the conflict cannot be avoided, there is no norm at all and any gap has to be filled by analogy with another norm.

(4) A conflict can be avoided by teleological reduction, whereby the intentions of the lawmaker are sought to be discerned, and if the wording of the law is broader than the intention, the law can be reduced to the intention.

\section{B Option One: Resolution by Interpretation}

It is difficult to avoid the conflict between ss $6 \mathrm{a}$ and 40 and following of the AMG by interpretation. First, s 40 and following are general in the sense that all medicinal products are to be clinically tested before they can enter the market. In spite of that, s 6a of the AMG generally prohibits the sale of doping substances. If sports doctors undertake a controlled clinical trial with one prohibited substance, it might be allowed under the conditions named in these norms for the clinical trial. On the other hand, the special norm against doping substances is applicable to all uses in sports whether in public events or in private trials. Since both norms have the same rank and have been promulgated together, there is a clash that cannot be resolved by interpretation. 


\section{Option Two: A Superior Norm takes Precedence}

As the clash cannot be resolved by interpretation, it must be decided what should be done with plainly contradictory rules. The prevailing opinion is that the rules cancel each other out so that there is no rule at all. ${ }^{19}$ That would mean that doping substances can be freely tested and that clinically controlled trials are not necessary to certify doping substances. It must then be decided how the gap created by the contradictory rules should be filled. A new rule would have to be created that fits the circumstances and follows the intention of the statute. It is difficult to decide which former rule should prevail. Doping substances are clearly forbidden, and clinically controlled trials are the norm. It must be noted that doping substances are not ordinary drugs. To allow controlled clinical trials would be contrary to the intention of s 6a of the AMG. On the other hand, the prohibition against the possession of doping substances does not make sense if the substance does not improve the corporal facilities of the sportsperson or is dangerous to that person.

\section{Section 6a of the AMG: Criminal Acts}

Section 6a has been part of the AMG since 1998. It has been upheld subsequently, most recently in 2012. The interpretation of s $6 \mathrm{a}$ of the AMG, which together with s 98 regulates the possession of medicinal products for doping purposes, is based in criminal law. Criminal law uses strict interpretation rules, and so it has been with the interpretation of the meaning of "small amount" by the Federal Supreme Court, discussed above. ${ }^{20}$

It would not be easy to interpret s 6 a in order to allow controlled clinical trials with a "small amount" of a doping substance, because s 6a encompasses all uses of doping substances and there is no way to read down the text to allow controlled clinical trials. In any case, it is difficult to limit a criminal statute by falling back on its original meaning. The inevitable conclusion is that the norm collision between s 6a of the AMG and s 40 and following of the AMG remains. No one has proposed limiting s $6 \mathrm{a}$ of the AMG in this regard.

\section{Section 40 and following of the AMG: Controlled Clinical Trials}

Controlled clinical trials must be regulated because medicinal products have to be tried out on humans before they are allowed to be distributed. The rule relating to controlled clinical trials is very general and applies to all kinds of chemical substances to be used on humans. To limit s 40 and following in the case of doping substances would not be easy. Doping substances are medicinal products as defined in s 2 of the AMG, and all such products should be tested before they are used on persons in sports.

19 Enneccerus Allgemeiner Teil (12th ed, 1928) at [53] I 3.

20 BGH A\&R 2012, above n 17. 
A limitation of the rules relating to controlled clinical trials would be against the will of Parliament and everything scholars have written about controlled clinical trials.

\section{Option Three: Resolution by Analogy}

In resolving the conflict in the AMG, it is possible to work with analogies, but analogies have drawbacks which should be taken into account. Analogy can only be used where regulation was expected but was overlooked. Sometimes the need for an analogy arises after the statute has been published. Then it is necessary to look at comparable regulations and adopt one by analogy. While this is not easy, it is sometimes possible. There has to be a compelling reason to use an analogy. This was the case with the so-called doctrine of "positive breach of contract". ${ }^{21}$

That doctrine came about because the German law of obligations, contained in the German Civil Code, originally recognised only breaches due to impossibility of performance or delay. That meant that there was no remedy for situations where, for example, a debtor performed a contract imperfectly or breached accompanying contractual duties. It is unclear whether the committee which prepared the Civil Code intentionally limited remedies in that way, or had simply not noticed the need for regulation. As a result of that gap in the law of obligations, judges began applying the doctrine of "positive breach of contract" to address situations where either the specific contract provisions did not include a remedy for faulty performance, or where a creditor who had suffered a loss resulting from a breach of collateral duty would not otherwise be compensated. ${ }^{22}$ The rules of delay from the Civil Code were applied by analogy. ${ }^{23}$

In the context of this article, another limitation on the use of analogies is that, as far as criminal law is concerned, extension of the application of the criminal law in malam partem by analogy is not allowed. Article 103, abs 2 of the Basic Law (Grundgesetz) only allows acts to be punished where they were defined by the law as a criminal offence before they were committed.

\section{E Option Four: Resolution by Teleological Reduction}

\section{Origins of teleological reduction and limits on its use}

Teleological reduction has been used in private law for many years. It is especially necessary for a system of codification which has to use broad expressions. These expressions and their wordings have to be controlled to fulfil the intention of the lawmaker.

21 In German, "Positive Vertragsverletzung".

22 Peer Zumbansen "The Law of Contracts" in Matthias Reimann and Joachim Zekoll (eds) Introduction to German Law (2nd ed, Kluwer Law International, The Hague, 2005) 179 at 192.

23 Konrad Zweigert and Hein Kötz Introduction to Comparative Law (translated by Tony Weir, 3rd ed, Clarendon Press, Oxford, 1998) at 494. A reform of the law of obligations in 2002 codified a new remedy which filled that gap and rendered the doctrine unnecessary. 
The phrase "teleological reduction" was used first by Karl Larenz in 1960 in his book Methodenlehre der Rechtswissenschaft. ${ }^{24}$ It has found acceptance in German methodology and in private law. ${ }^{25}$ The number of applications of teleological reduction is legion. ${ }^{26}$

The word "reduction" implies that there is a larger norm that must be reduced. Therefore the enlargement of a small norm is not teleological reduction. It might be some form of teleological implantation, but that is another story. Teleological reduction can only lead to the limiting of the text of a statute. Reduction does not just mean that the larger norm is not being applied but that the norm has specified limitations.

To employ teleological reduction there must be a statute which is written in a broad way and which can be limited so that it fits the intention of the lawmaker. This is the easy way of getting out of a norm conflict. ${ }^{27}$

\section{Sociological grounds for employing teleological reduction}

Sociological reduction is another term for teleological reduction. Sociology in this field refers to the protection of certain groups of individuals by a norm, which has lost its ability to protect someone. Larenz gives a famous example of this. According to s 181 of the German Civil Code an agent is, unless permission is given, not allowed to act both as an agent for someone else and as himself at the same time. According to that rule, if a father wanted to give his minor child a present, the contract would be null and void. However, that result would disadvantage the minor and run counter to the intention of $\mathrm{s} 181$, which is to protect the principal. ${ }^{28}$

For the purpose of establishing the safety and efficacy of the substances used for doping, it is necessary to allow controlled clinical trials of these substances. There are rules concerning general and special medical trials. If the norm collision method is not followed, there are other ways to avoid the prohibition of $s 6$ a of the AMG.

First, there are the general rules in s 6a, subss 1 and 2 of the AMG among which we have to establish an exemption for controlled clinical trials. Secondly, s 40 of the AMG, which states general rules for clinical trials, could be applied. The second step could only be taken if clinical trials of doping substances are allowed in general.

24 Karl Larenz Methodenlehre der Rechtswissenschaft (2nd ed, Springer Verlag, Berlin, 1969).

25 Franz Bydlinski Juristische Methodenlehre und Rechtsbegriff (Springer Verlag, Wien, 1982) at 480; and Münchener Kommentar zum Bürgerlichen Gesetzbuch (5th ed, Verlag C H Beck, Munich, 2010) vol 2 at s 277 , no 2 .

26 Larenz, above n 24, at 396 and following.

27 Larenz, above n 24, at 396 and following; and F Bydlinski, above n 25, at 480.

28 Larenz, above n 24. 
According to German criminal law, either the general rule has to be rolled back or a justification for the clinical trial has to be found. Both ways are equally useful because all concerned with a clinical trial are not subject to the general criminal rule of s 6a of the AMG. As a measure of justification, s 34 of the German Criminal Statute (Strafgesetzbuch), "necessity as justification", could be applied if the value of the clinical trial would be superior to the statutory provision.

\section{Current applications of teleological reduction to the $A M G$}

The text of s 40 of the AMG contains provisions limiting the use of clinical trials. For example, according to s 40, subs 1 , para 2 of the AMG, a clinical trial may only proceed if the foreseeable risks and inconveniences of the trial are medically justifiable when compared with the benefit for the person on whom the trial will be conducted, and the anticipated significance of the medical product for medical science. In respect of this condition, the text must be altered to allow it to accord with the intention of the lawmaker. The lawmaker wanted to allow clinical trials with possible utility for the patient, but also wanted to allow purely scientific trials with no possible utility for the patient (but with limited risks for the patient) for the benefit of medical science generally. To allow such tests, it is necessary to substitute the "and" with "or" in the AMG; this is now routinely done. The statute was, from the beginning, intended to allow purely scientific trials. The substitution of the word "or" means a purely scientific test can be done which does not hurt the patient but which allows a real need of medical science to be met.

There are other places in the AMG where teleological reduction has to be used. The main reason is the text of s 40 of the AMG. While it seems that all clinical trials should be allowed under certain conditions, that is not obvious from the text. An example could be the controlled clinical trial of a new substance substituting one substance instead of more than one. That trial would not have any use for the patients concerned, but would be effective for medicine in general.

\section{Overall text and reality of clinical trials}

According to a literal reading of s 40 of the AMG, a clinical trial should involve just one patient. This is rarely the case. Therefore other criteria are used for clinical trials. In clinical trials at least two groups are compared with each other. One consists of ill persons (the test group) and the other of healthy persons, or patients with a different illness (the control group) ${ }^{29}$

All kinds of comparisons can be made between the two groups: there might be an exchange of the members of the test group and of the control group; there might be a time-gap before the starting of the test; or the controlled clinical trial could be split up into sub-groups, sometimes a bewildering number of sub-groups named (after the Roman military formations) cohort studies.

29 Kloesel and Cyran, above n 3, at s 40, no 20; and Deutsch and Spickhoff, above n 3, at no 1304. 


\section{GIVING INFORMATION ABOUT THE TRIAL}

\section{A Informing the Trial Subjects: Informed Consent}

In European law the most important prerequisite of a controlled clinical trial is informed consent. ${ }^{30}$ The proband has to consent to being given the medication knowing its contents, and the consent has to find its basis in information given to the proband. In the context of a trial of doping substances, the proband would have to be informed about the alleged doping drug, its expected results and its dangers. The consent must be based on this knowledge.

\section{$B$ Information to Others}

Depending on how any clinical trial involving using doping substances on cyclists is carried out, there may be no need to inform anyone else about the trial once the necessary authorisation is obtained. However, the doped cyclists may end up racing other cyclists who have not taken doping substances, and could potentially win a competition or trophy. If this is the case, the other competitors would have to be informed about their colleagues cycling under the influence of an alleged doping substance. The organiser of the event must also then be informed. If betting is allowed on the event, then the fact of the trial of doping substances will probably have to be publicly announced, otherwise the public might be misinformed.

If the necessary information is not given to the public, or it contains obvious mistakes, a delict could be committed according to s 823 and following of the Bürgerliches Gesetzbuch (BGB), and there could be liability in damages. It would amount to foul play if the information were not given. If there is a duty to inform a certain group, its violation allows only the members of the protected group to bring a claim for damages as a result of the misinformation.

\section{WHAT IS THE APPLICABLE LAW?}

The question of applicable law commonly arises within sports law because of the cross-border nature of many sporting endeavours. It may arise in the context of any clinical trials of doping substances because, for example, the bodies regulating a particular sport (for example, cycling) may be situated in a different jurisdiction than that where the trial is taking place. There may also be participants and other interested parties who are foreign nationals.

\section{A International Criminal Law: Law of the Place where the Sports Event Takes Place}

Section 6a of the AMG is a criminal provision, so it is tempting to use the law where the crime is committed as the applicable law. The general rule in criminal law is lex loci delicti commissi: the law of the location where the offence has taken place. In some countries, Germany among them, the "personal principle" (the principle that the German criminal law "follows" German nationals)

30 Rehmann, above n 4 , at s 40 , no 8. 
overrules the international criminal law, at least when the criminal act is committed by a German and is directed against another German. This will rarely be the case with doping substances, except maybe where the sportsperson receives the doping substance without knowledge that it is a prohibited medication. If the international criminal law does not follow the lex loci, but uses the personal principle, it might be possible to apply the personal law of the sportsperson.

\section{B International Private Law: Contract}

Under contract law, the parties to a contract can control the applicable law if they have expressly chosen a certain law in their contract. ${ }^{31}$

Prior to 2008, if the parties had not agreed on an applicable law, according to the German judicature, the courts had to look to the law they would have chosen. A hypothetical meeting of the minds was applied. ${ }^{32}$

In 2008, the European Union issued a regulation on contract which was immediately applicable in all European states. It is called the Convention on the Law Applicable to Contractual Obligations and is most commonly known as "Rome I". ${ }^{33}$ Article 3 of Rome I states that a contract is governed by the law that the parties have chosen. In contracts concerning doping substances the parties very often agree on an applicable law. Ordinarily the parties will try to use the law that is most permissive to the trainer and the sportsperson. Sometimes then ordre public (art 6 of the German Introductory Act to the Civil Code) will have to be used. Normally, even according to the law the parties have chosen, the contract will be null and void if it runs against a general public policy banning doping substances.

If the parties have not expressly chosen the applicable law, art 4 of Rome I applies. Article 4(1) and (2) sets out criteria to determine which law should apply. However, art 4(3) of Rome I provides that if all the circumstances show that the contract is manifestly more closely connected with a country other than that indicated in paras (1) and (2), the applicable law will be the law of that country. ${ }^{34}$ In the case of sports events, the law where the event takes place will ordinarily take precedence over all other laws, unless the parties have expressly agreed otherwise. The parties and the audience assume that the local law is applicable and this assumption should not be disregarded, even if the contract is, according to most laws, null and void. The law of the state most closely

31 Gerhard Kegel and Klaus Schurig Internationales Privatrecht (8th ed, Verlag C H Beck, Munich, 2000) at s 18 I; and Martin Wolff Das International Privatrecht Deutschlands (3rd ed, Springer Verlag, Berlin, 1954) at s 28 II.

32 Wolff, above n 31, at 142 and following; and Kegel and Schurig, above n 31, at s 18 I.

33 Bamberger, Roth and Spickhoff BGB, Rom I-VO. Regulation 593/2008 on the Law Applicable to Contractual Obligations [2008] OJ L177/6.

34 Compare Bamberger, Roth and Spickhoff, above n 33, art 4 no 82; and Palandt and Thorn EGBGB, art 28, no 1. 
connected with the sports event, that is the location where the sport takes place, is the preferable law. If the sports event touches on more than one country, for instance the Tour de France, the law of the main event is applicable (French law). If the contract between a trainer and a supplier for the drug can be used in different sports in different locations, the country most closely connected with the contract will have to be established by critical analysis. All circumstances are to be regarded, so that even the common citizenship of the supplier and the trainer might point to the law applicable to the contract.

\section{International Private Law: Tort, Delict, Responsabilité Civile}

As far as the international law of delict is concerned, prior to 2007 the law of the place where an act started, or the law of the place where the result became apparent, was applied. Therefore the law of the place where the violation of the person or right occurred took precedence over the law of the place where the damage occurred. ${ }^{35}$ In 2007 the European Union issued a Regulation called the Convention on the Law Applicable to Non-contractual Obligations, commonly known as "Rome II". ${ }^{36}$ This regulation established a totally new approach. According to art 4(1) of Rome II, noncontractual liability is determined by the law of the state where the damage occurs. The state in which the major event or some indirect damage has taken place has to be disregarded. This new approach follows the French law which always applied the law where the damage occurred.

However, art 4(2) provides that where both parties have their habitual residence in the same country when the damage occurs, the law of that country will apply. Furthermore, art 4(3) of Rome II states that where it is clear from all the circumstances of the case that the delict is manifestly more closely connected with a country other than that specified by art 4(1) or (2), then the law of that country prevails. ${ }^{37}$ This rule can be applied in some cases where doping substances play a role in a sports event; usually then the law where the sports event takes place will be applied. However, it can be the case that the doping substance is used in different locations or that the contract touches on different laws; then the general rule contained in art 4(1) might be more appropriate. In these cases, the law of the place where the damage occurred will be better suited to cover the liability. Finally, if different laws are applicable, all the laws run concurrently. The use of doping substances in a clinical trial without telling anyone that one cyclist is using the doping substance is a delict. Therefore the norm of the state where the damage occurs is to be applied.

\section{Law of the Place where the Main Regulatory Commission is Situated}

Many European, or even world, events are regulated by sports commissions situated predominantly in Switzerland. These regulatory agencies issue regulations for the sport. These

35 Wolf, above n 31, at s 31; and Kegel and Schurig, above n 31, at s 18 IV.

36 Regulation 864/2007 on the Law Applicable to Non-contractual Obligations [2007] OJ L199/40.

37 See Bamberger, Roth and Spickhoff, above n 33, art 12; and Palandt and Thorn, above n 34, art 4, no 14. 
regulations tell the participants what they can and cannot do. They can even go so far as to regulate violations and exclude a sportsperson for some time from participation.

As far as the code of conduct is concerned, the law of the place where the regulatory commission is situated applies. Sometimes when violations of rules or even penalties are to be considered it might be better to look at the law where the violation occurred. Therefore in one event two laws might apply: as far as the rule of behaviour is concerned, the Swiss law is applicable. On the other hand, if the violation is to be judged or a penalty imposed the law of the state where the sport event took place might be chosen. Therefore, even if an international commission has issued a ruling, it is better that the law where the violation took place is applicable than the distant Swiss law. The public would not understand if the ruling of the commission against a player were based on Swiss law which no one at the place where the sport events is being held understands.

\section{CONCLUSION}

Controlled clinical trials on cyclists with alleged doping substances are not prohibited in Germany. They are allowed.

These trials require the informed consent of the cyclist. Depending on the circumstances, others may have to be informed too. These may include an event's competitors and organisers, and the public. If any duty to inform is violated, there will be grounds for a claim for breach of duty under ss 280 or 823 of the BGB.

In international criminal law, the lex loci delicti commissi is usually the applicable law, with the exception of the rarely used personal principle. If a contract about doping substances is concluded, the law that the parties have chosen is applicable. Otherwise the law of the place where the sports event is conducted will usually be applicable. It is nearly the same in the international law of delict. Normally the majority of factors will point to the applicable law being the law of the place where the sports event is taking place. Rarely, especially if players of different nationalities participate, the general rule will be used and the law of the place where the damage occurred applied.

If an ethics committee has to consider an application for a controlled clinical trial with doping substances, it should generally give its approval. 